7-31-2019

\title{
Evaluating the implementation and quality of an extension initiative: The case of Sambalaran Camp Project
}

Judith Gabatin

Bulacan State University - Meneses Campus, Philippines, judithgabatin2@gmail.com

Michelle Divino

Bulacan State University - Meneses Campus

See next page for additional authors

Follow this and additional works at: https://scholarhub.ui.ac.id/ajce

Part of the Social and Behavioral Sciences Commons

\section{Recommended Citation}

Gabatin, Judith; Divino, Michelle; and Camua, Ma. Daisy (2019). Evaluating the implementation and quality of an extension initiative: The case of Sambalaran Camp Project. ASEAN Journal of Community Engagement, 3(1).

Available at: https://doi.org/10.7454/ajce.v3i1.173

Creative Commons License

(c) (i) (2)

This work is licensed under a Creative Commons Attribution-Share Alike 4.0 License.

This Research Article is brought to you for free and open access by the Universitas Indonesia at ASEAN Journal of Community Engagement. It has been accepted for inclusion in ASEAN Journal of Community Engagement. 


\title{
Evaluating the implementation and quality of an extension initiative: the case of Sambalaran Camp Project
}

\author{
Judith Gabatin ${ }^{a^{*}}$, Michelle Divinoa, Daisy Camua ${ }^{a}$ \\ a Bulacan State University, Meneses Campus, Philippines
}

Received: April 30th 2019 || Revised: May 10 th, 2019 || Accepted: June 21 2019

\begin{abstract}
With the implementation of extension projects by higher education institutions, particularly by state universities and colleges, it is imperative that they undergo the continuous and relevant phases of monitoring and evaluation. Hence, feedbacks that can be obtained from the project's beneficiaries are deemed necessary to improve and inform the whole process of conducting any extension activity. Considering the role of feedback mechanisms, this study sought to evaluate the implementation and quality of the Sambalaran Camp Project, which was carried out by the extension office of Bulacan State University - Meneses Campus in Bulacan Province, Philippines in its partner and adopted communities in the towns of Bulakan and Guiguinto last 2017 and 2018. Results show that most of the 154 beneficiaries reported a strong level of agreement towards the implementation of the project. They also reported positive ratings, ranging from very good and excellent, in assessing the project's quality. Open-ended qualitative responses revealed that they were interested in opening small business after gaining new knowledge and skills. T-test analysis revealed that the first batch (2017) of beneficiaries reported higher both level of agreement and positive rating than the second batch (2018), reflecting the latter's observations concerning the lack of required training materials and allotment of minimal amount of time for a skills training activity.
\end{abstract}

Keywords: extension, university, evaluation, feedback

\section{Introduction}

As one of the three core mandates of state universities and colleges (SUCs) in the Philippines, extension focuses on the improvement of the target beneficiaries' quality of life through direct communication, empowerment, and provision of various programs, services, and activities (Education, 2008). Hence, as stipulated in the Higher Education Modernization Act of 1997, the establishment of extension centers in SUCs and their further promotion and development through research are imperative undertakings.

The implementation of community engagements has thus become a core practice of higher education institutions. This only suggests that universities and colleges are becoming more accountable and committed to addressing the needs of communities (Oaks, Franklin, \& Bargerstock, 2008). With the availability of educators who are 
Judith Gabatin, Michelle Divino, Daisy Camua | ASEAN Journal of Community Engagement | Volume 3, Number 1, 2019

commonly tapped as experts, the conduct of extension-related activities become a relevant activity. These educators serve as the link between knowledge, as the key resource produced by the university, and the needs that originate from the communities (Stocker, 2014).

The crucial role of extension providers does not end in the implementation of a project; it has to be extended to the continuous and tedious process of decision-making as a key component of monitoring and evaluation. There are instances when they find out that the results of their hard work may still be unacceptable; hence, they have to proceed to observing the evaluation results and improving their decisions (Warner, 2014). At first glance, what they undertake might seem like a trial-and-error process. It is in this context that educators should go beyond such process for it requires a more careful and systematic attempt, that is, by integrating research skills in the conduct of extension as a means to discover new evidence-based information (Jackson \& Thomas, 2003).

Directly linked to the concept of effectiveness, evaluation allows implementers to assess their performance as extension service providers (Lynton, 1996). Specifically, when evaluation is supported by subjective and objective data, it becomes a relevant basis for faculty members and students to enhance the way they effectively carry out an extension program (McKinnis, Sloan, Snow, \& Garimella, 2014). However, this is easier said than done for it requires an assessment of the overall nature of an extension program. By holistically examining the program's context, inputs, processes, outputs, and outcomes, evaluation becomes a necessary tool for indicating what particular changes are required to be made for both present and future implementation of the program (Madaus, Scriven, \& Stufflebeam, 2002; UNESCO, 2015).

The value of evaluation can also be linked to the concept of feedback. Whether positive or negative, feedback becomes a relevant input to the decision-making process (Warner, 2014). Responsive and continuous feedback informs the process by engaging all those involved in the partnership to facilitate the development of meaningful and sustainable partnerships. The findings collected through such feedback mechanism inform the phases involved in future engagements or partnerships (Mosse \& Bottrell, 2015). They also allow implementers to assess priorities based on the assessment of needs and build the capacities not only of the beneficiaries but also of themselves (Simmons et al., 2015). Feedback is thus a crucial component that should be present in every phase of a program (Zhang et al., 2011). Without feedbacks in the evaluation process, the decision-making 
Judith Gabatin, Michelle Divino, Daisy Camua | ASEAN Journal of Community Engagement | Volume 3, Number 1, 2019

process is likely to neglect valuable information that could solve implementation problems or provide recommendations for the program's enhancement.

In Bulacan State University - Meneses Campus (BulSU-MC), the relevance of acting upon the feedbacks seemed to have been taken for granted throughout the previous years of implementing several extension services. Feedbacks are usually gathered from the target beneficiaries through interviews and evaluation forms; however, the feedback mechanisms are not maximized to the fullest as most of the documents were only kept for filing, not for assessing and discussing with the service providers as well as target beneficiaries the potential challenges or suggestions for the improvement of the project. The reports are particularly crucial in determining whether the management of resources, budget, and staff was still relevant to the conduct of the plan.

This study therefore highlights the importance of monitoring and evaluating extension activities conducted specifically by the Campus. The activities included in this evaluation study were part of the Sambalaran (which stands for "Sama na sa Pambayang Kaunlaran," translated in English as "Participate in the National Development") Camp Project crafted by the University Extension Office and was launched in 2017. The project was again implemented in 2018 as it was designed to become an integral component of BulSU's core mandates and to serve as a primary venue for carrying out projects in adopted communities in the province of Bulacan. It has three key goals: (1) to serve as a venue for the conduct of Community Development Summit in the province that would highlight the successes of the chosen adopted communities; (2) to become a regional organization aimed at empowering communities towards progress and development; and (3) to establish its training arms in the different towns of the province (Bulacan State University - University Extension Office, 2017).

In particular, the extension program carried out by BulSU-MC consisted of seminarworkshops facilitated by faculty members and students of hospitality management, business administration, and teacher education departments. In 2017, the activities carried out by the Campus primarily focused on solid waste management, financial wellness, and food preservation. In 2018, the only extension service offered was food preservation. The target beneficiaries included community residents from the municipalities of Bulakan and Guiguinto, where the Campus has existing memoranda of agreement. They consisted of mother leaders, beneficiaries of conditional cash transfer program, and mothers of children with special needs. 
Judith Gabatin, Michelle Divino, Daisy Camua | ASEAN Journal of Community Engagement | Volume 3, Number 1, 2019

Considering the foregoing statements, this research seeks to evaluate the implementation and quality of Sambalaran Camp Project which was carried out in 2017 and 2018. It has the following specific objective of determining the beneficiaries' attitudes towards the implementation and quality of the different components of the project, finding out their perceptions and recommendations regarding the conduct of the project, and determining whether a significant difference exists between the first batch and second batch of beneficiaries as regards their attitudes towards the implementation and quality of the project.

\section{Methods}

This evaluation study, which used a descriptive research design, was carried out with 154 beneficiaries of the Sambalaran Camp Project activities conducted by the Campus in 2017 and 2018. Specifically, 74 beneficiaries received trainings in financial wellness, solid waste management, and food preservation at the Campus in 2017; 80 beneficiaries attended the food preservation training, which was the only extension service offered by the campus in three barangays or villages in 2018.

The trainings provided to them were initially identified through needs assessment, which was carried out to determine the context by which the project was implemented. What was specifically looked into was the socio-economic environment of the target beneficiaries. Aside from the needs, the resources of the Campus and the potential challenges in implementing the project were assessed to facilitate better decisionmaking. It was also during this stage that a pool of faculty members, who would serve as extension service providers, was identified. It was determined that instructors from the Business Administration Departments and Hospitality Management

The findings from the need's assessment served as the bases for crafting the project's operation plan. The plan was designed based on the available resources and capabilities of the faculty. It contains the following vital components of the project: proponents, rationale and objectives, target beneficiaries, duration and date of implementation, budgetary requirements, and recommendations (Bulacan State University - University Extension Office, 2017).

After the conduct of each training, each beneficiary was asked to fill out an evaluation form. Such evaluation was geared towards examining the extent to which the project was able to accomplish its objectives. This was carried out through the use of both 
Judith Gabatin, Michelle Divino, Daisy Camua | ASEAN Journal of Community Engagement | Volume 3, Number 1, 2019

quantitative and qualitative evaluations. Before they answered the form, the beneficiaries or participants were oriented about its purpose. They were told that their answers would be utilized for the purpose of reporting their overall perception about the project and that the any information they provided to the researchers would be treated with confidentiality.

The researchers adapted the evaluation questionnaire designed and validated by extension service experts from the BulSU-UEO and published in its 2017 manual of operations. The instrument is a documented information tool that had been used in all the extension undertakings of the various college- or campus-based extension units of the University. The evaluation form, which is originally written in Filipino, consisted of 15 items on the different components of the training and 2 open-ended questions, which asked what aspect of the project should still be improved and if they had recommendations. The items were rated on 5-point Likert scales, ranging from "strongly disagree" to "strongly agree" and "poor" to "excellent."

This study employed descriptive statistics such as frequency, percentage, and mean. An independent samples t-test was used to compare the means of the perceptions between the two batches of beneficiaries (i.e., by year, 2017 and 2018). For the openended responses, the responses were further examined so that qualitative findings emerging from this would lend complementary support to the quantitative findings.

\section{Result and Discussion}

\subsection{Quantitative Evaluations Results}

\subsubsection{Beneficiaries'Attitudes Toward the Implementation 2017 Sambalaran Camp Project}

The evaluation of this extension project included 74 female beneficiaries. They were residents of barangays in the towns of Guiguinto $(\mathrm{N}=67)$ and Bulakan $(\mathrm{N}=7)$ where the adopted and partner communities of BulSU-MC could be found. Specifically, they attended trainings on financial wellness $(\mathrm{N}=55)$, solid waste management $(\mathrm{N}=6)$, and food preservation $(\mathrm{N}=13)$ at the campus.

The quantitative evaluation results found that the beneficiaries strongly agreed on how each component of the seminar-workshop was carried out, as reflected in the 13 mean responses corresponding to strong agreement. As indicated in Table 1, the strongest level of agreement was recorded in the statement concerning the 
Judith Gabatin, Michelle Divino, Daisy Camua | ASEAN Journal of Community Engagement | Volume 3, Number 1, 2019

knowledgeability of the speaker $(\mathrm{M}=4.84)$ while the lowest level of agreement was indicated in the statement on allotment of enough time for the activity $(M=4.47)$.

Table 1. Frequency distribution of participants' attitudes and mean responses toward the implementation of 2017 Sambalaran Camp Project

\begin{tabular}{|c|c|c|c|c|c|c|c|c|c|c|c|c|}
\hline \multirow[t]{2}{*}{ Item } & \multicolumn{2}{|c|}{$\begin{array}{c}\text { Strongly } \\
\text { agree }\end{array}$} & \multicolumn{2}{|c|}{ Agree } & \multicolumn{2}{|c|}{$\begin{array}{l}\text { Fairly } \\
\text { Agree }\end{array}$} & \multicolumn{2}{|c|}{ Disagree } & \multicolumn{2}{|c|}{$\begin{array}{l}\text { Strongly } \\
\text { disagree }\end{array}$} & \multirow[t]{2}{*}{ Mean } & \multirow{2}{*}{$\begin{array}{c}\text { Verbal } \\
\text { Interpre } \\
\text { tation }\end{array}$} \\
\hline & $\mathrm{F}$ & $\%$ & $\mathrm{~F}$ & $\%$ & $\mathrm{~F}$ & $\%$ & $\mathrm{~F}$ & $\%$ & $\mathrm{~F}$ & $\%$ & & \\
\hline $\begin{array}{l}\text { 1. Achieved } \\
\text { expectations }\end{array}$ & 61 & 82.4 & 10 & 13.5 & 3 & 4.1 & - & - & - & - & 4.78 & $\begin{array}{c}\text { Strongly } \\
\text { Agree }\end{array}$ \\
\hline $\begin{array}{l}\text { 2. Knowledge } \\
\text { gained could be } \\
\text { applied to future } \\
\text { endeavors. }\end{array}$ & 60 & 81.1 & 12 & 16.2 & 1 & 1.4 & - & - & 1 & 1.4 & 4.75 & $\begin{array}{c}\text { Strongly } \\
\text { Agree }\end{array}$ \\
\hline $\begin{array}{l}\text { 3. Accomplished } \\
\text { objectives }\end{array}$ & 60 & 81.1 & 10 & 13.5 & 4 & 5.4 & - & - & - & - & 4.76 & $\begin{array}{c}\text { Strongly } \\
\text { Agree }\end{array}$ \\
\hline $\begin{array}{l}\text { 4. Organized and } \\
\text { easy-to-follow } \\
\text { contents }\end{array}$ & 61 & 82.4 & 10 & 13.5 & 2 & 2.7 & - & - & 1 & 1.4 & 4.74 & $\begin{array}{c}\text { Strongly } \\
\text { Agree }\end{array}$ \\
\hline $\begin{array}{l}\text { 5. Knowledge } \\
\text { gained was } \\
\text { useful }\end{array}$ & 62 & 83.8 & 8 & 10.8 & 3 & 4.1 & - & - & 1 & 1.4 & 4.76 & $\begin{array}{c}\text { Strongly } \\
\text { Agree }\end{array}$ \\
\hline $\begin{array}{l}\text { 6. Resources } \\
\text { shared were } \\
\text { useful }\end{array}$ & 61 & 82.4 & 11 & 14.9 & 2 & 2.7 & - & - & - & - & 4.80 & $\begin{array}{c}\text { Strongly } \\
\text { Agree }\end{array}$ \\
\hline 7. & & & & & & & & & & & & \\
\hline $\begin{array}{l}\text { Seminar/training } \\
\text { appropriate to } \\
\text { needs. }\end{array}$ & 61 & 82.4 & 10 & 13.5 & 3 & 4.1 & - & - & - & - & 4.78 & $\begin{array}{c}\text { Strongly } \\
\text { Agree }\end{array}$ \\
\hline 8. & & & & & & & & & & & & \\
\hline $\begin{array}{l}\text { Speakers/trainer } \\
\text { s were } \\
\text { knowledgeable }\end{array}$ & 66 & 89.2 & 5 & 6.8 & 3 & 4.1 & - & - & - & - & 4.84 & $\begin{array}{c}\text { Strongly } \\
\text { Agree }\end{array}$ \\
\hline
\end{tabular}


Judith Gabatin, Michelle Divino, Daisy Camua | ASEAN Journal of Community Engagement | Volume 3, Number 1, 2019

\begin{tabular}{|c|c|c|c|c|c|c|c|c|c|c|c|c|}
\hline \multirow[t]{2}{*}{ Item } & \multicolumn{2}{|c|}{$\begin{array}{c}\text { Strongly } \\
\text { agree }\end{array}$} & \multicolumn{2}{|c|}{ Agree } & \multicolumn{2}{|c|}{$\begin{array}{l}\text { Fairly } \\
\text { Agree }\end{array}$} & \multicolumn{2}{|c|}{ Disagree } & \multicolumn{2}{|c|}{$\begin{array}{l}\text { Strongly } \\
\text { disagree }\end{array}$} & \multirow[t]{2}{*}{ Mean } & \multirow{2}{*}{$\begin{array}{l}\text { Verbal } \\
\text { Interpre } \\
\text { tation }\end{array}$} \\
\hline & $\mathrm{F}$ & $\%$ & $\mathrm{~F}$ & $\%$ & $\mathrm{~F}$ & $\%$ & $\mathrm{~F}$ & $\%$ & $F$ & $\%$ & & \\
\hline $\begin{array}{l}\text { 9. Ensured the } \\
\text { quality of the } \\
\text { activity }\end{array}$ & 60 & 81.1 & 9 & 12.2 & 4 & 5.4 & - & - & 1 & 1.4 & 4.71 & $\begin{array}{c}\text { Strongly } \\
\text { Agree }\end{array}$ \\
\hline 10. & & & & & & & & & & & & \\
\hline $\begin{array}{l}\text { Speakers/trainer } \\
\text { s were able to } \\
\text { meet the } \\
\text { objectives }\end{array}$ & 62 & 83.8 & 9 & 12.2 & 3 & 4.1 & - & - & - & - & 4.80 & $\begin{array}{c}\text { Strongly } \\
\text { Agree }\end{array}$ \\
\hline $\begin{array}{l}\text { 11. Encouraged } \\
\text { participation/int } \\
\text { eraction }\end{array}$ & 58 & 78.4 & 14 & 18.9 & 2 & 2.7 & - & - & - & - & 4.76 & $\begin{array}{c}\text { Strongly } \\
\text { Agree }\end{array}$ \\
\hline $\begin{array}{l}\text { 12. Allowed } \\
\text { sharing of } \\
\text { insights }\end{array}$ & 58 & 78.4 & 13 & 17.6 & 3 & 4.1 & - & - & - & - & 4.74 & $\begin{array}{c}\text { Strongly } \\
\text { Agree }\end{array}$ \\
\hline $\begin{array}{l}\text { 13. Enough } \\
\text { allotted time for } \\
\text { the activity }\end{array}$ & 49 & 66.2 & 14 & 18.9 & 9 & 12.2 & 2 & 2.7 & - & - & 4.47 & Agree \\
\hline $\begin{array}{l}\text { 14. Enough time } \\
\text { allotted for open } \\
\text { forum }\end{array}$ & 50 & 67.6 & 13 & 17.6 & 10 & 13.5 & 1 & 1.4 & - & - & 4.51 & $\begin{array}{c}\text { Strongly } \\
\text { Agree }\end{array}$ \\
\hline
\end{tabular}

Source: Author (2017)

Almost all (97.3\%) of them either strongly agreed or agreed to the training components pertaining to the application knowledge gained to future endeavors (2nd item), usefulness of the resources shared (6th item), and encouragement of participation among the participants (11th item).

High positive ratings were also given by the beneficiaries to six components of the project. Virtually all (95.9\%) of them answered "strongly agree" or "agree" to items how the seminars and trainings successfully achieved and met their expectations (1st item), incorporated organized and easy-to-follow contents (4th item), became appropriate to their needs (7th item), tapped knowledgeable speakers/trainers (8th item), met the objectives through the trainers (10th item), and allowed sharing of insights (11th item). 
Judith Gabatin, Michelle Divino, Daisy Camua | ASEAN Journal of Community Engagement | Volume 3, Number 1, 2019

Table 2. Frequency distribution of participants' overall attitudes and mean response toward the quality of 2017 Sambalaran Camp Project

\begin{tabular}{|c|c|c|c|c|c|c|c|c|c|c|c|c|}
\hline \multirow{2}{*}{ Statement } & \multicolumn{2}{|c|}{ Excellent } & \multicolumn{2}{|c|}{$\begin{array}{l}\text { Very } \\
\text { good }\end{array}$} & \multicolumn{2}{|c|}{ Good } & \multicolumn{2}{|c|}{ Fair } & \multicolumn{2}{|c|}{ Poor } & \multirow{2}{*}{ Mean } & \multirow{2}{*}{$\begin{array}{c}\text { Verbal } \\
\text { Interpret } \\
\text { ation }\end{array}$} \\
\hline & $\mathrm{F}$ & $\%$ & $F$ & $\%$ & $F$ & $\%$ & $F$ & $\%$ & $F$ & $\%$ & & \\
\hline $\begin{array}{l}\text { Overall, how } \\
\text { will you rate } \\
\text { the quality the } \\
\text { project? }\end{array}$ & 55 & 74.3 & 14 & 18.9 & 4 & 5.4 & - & - & 1 & 1.4 & 4.65 & Excellent \\
\hline
\end{tabular}

Source: Author (2017)

In general, as indicated in Table 2, a large majority (74.3\%) of the participants rated the extension project as an excellent undertaking. Less than a quarter (18.9\%) rated it as "very good." This particular Likert-type question had a mean score of 4.65, indicating that the project was perceived to be excellent by the beneficiaries.

\subsubsection{Beneficiaries' Attitudes Toward the Implementation 2018 Sambalaran Camp Project}

The evaluation of the food preservation training was carried out with 80 female beneficiaries who were also beneficiaries of the two existing extension projects (i.e., Oplan Kostal Aralan and Adopt Marcelo/SPED) of BulSU-MC in 2018. There were 3 batches of training conducted at San Nicolas ( $\mathrm{N}=32)$ and Taliptip ( $\mathrm{N}=22)$ in Bulakan and Poblacion $(\mathrm{N}=26)$ at Guiguinto.

The results indicated that the beneficiaries strongly agreed in nine out of 14 statements. Table 3 shows that the strongest level of agreement was found within the items pertaining to the organization of easy-to-follow contents $(M=4.58)$, usefulness of the knowledge gained from the trainings $(\mathrm{M}=4.58)$, and encouragement of the sharing of insights $(\mathrm{M}=4.58)$. The lowest level of agreement was recorded in the knowledgeability of the trainer $(M=4.37)$ 
80

Judith Gabatin, Michelle Divino, Daisy Camua | ASEAN Journal of Community Engagement | Volume 3, Number 1, 2019

Table 3. Frequency distribution of participants' attitudes and mean responses toward the implementation of 2018 Sambalaran Camp Project

\begin{tabular}{|c|c|c|c|c|c|c|c|c|c|c|c|c|}
\hline \multirow[t]{2}{*}{ Item } & \multicolumn{2}{|c|}{$\begin{array}{c}\text { Strongly } \\
\text { agree }\end{array}$} & \multicolumn{2}{|c|}{ Agree } & \multicolumn{2}{|c|}{$\begin{array}{l}\text { Fairly } \\
\text { Agree }\end{array}$} & \multicolumn{2}{|c|}{ Disagree } & \multicolumn{2}{|c|}{$\begin{array}{l}\text { Strongly } \\
\text { disagree }\end{array}$} & \multirow[t]{2}{*}{ Mean } & \multirow{2}{*}{$\begin{array}{c}\text { Verbal } \\
\text { Interpreta } \\
\text { tion }\end{array}$} \\
\hline & $F$ & $\%$ & $\mathrm{~F}$ & $\%$ & $\mathrm{~F}$ & $\%$ & $\mathrm{~F}$ & $\%$ & $\mathrm{~F}$ & $\%$ & & \\
\hline $\begin{array}{l}\text { 1. Achieved } \\
\text { expectations }\end{array}$ & 52 & 65.0 & 20 & 25.0 & 7 & 8.8 & - & - & 1 & 1.3 & 4.53 & $\begin{array}{l}\text { Strongly } \\
\text { Agree }\end{array}$ \\
\hline $\begin{array}{l}\text { 2. Knowledge } \\
\text { gained could } \\
\text { be applied to } \\
\text { future } \\
\text { endeavors. }\end{array}$ & 53 & 66.3 & 21 & 26.3 & 5 & 6.3 & - & - & 1 & 1.3 & 4.56 & $\begin{array}{l}\text { Strongly } \\
\text { Agree }\end{array}$ \\
\hline 3. & & & & & & & & & & & & \\
\hline $\begin{array}{l}\text { Accomplished } \\
\text { objectives }\end{array}$ & 51 & 63.8 & 20 & 25.0 & 8 & 10.0 & - & - & 1 & 1.3 & 4.50 & Agree \\
\hline $\begin{array}{l}\text { 4. Organized } \\
\text { and easy-to- } \\
\text { follow contents }\end{array}$ & 56 & 70.0 & 18 & 22.5 & 4 & 5.0 & 1 & 1.3 & 1 & 1.3 & 4.58 & $\begin{array}{c}\text { Strongly } \\
\text { Agree }\end{array}$ \\
\hline $\begin{array}{l}\text { 5. Knowledge } \\
\text { gained was } \\
\text { useful }\end{array}$ & 60 & 75.0 & 11 & 13.8 & 6 & 7.5 & 1 & 1.3 & 2 & 2.5 & 4.58 & $\begin{array}{l}\text { Strongly } \\
\text { Agree }\end{array}$ \\
\hline $\begin{array}{l}\text { 6. Resources } \\
\text { shared were } \\
\text { useful }\end{array}$ & 52 & 65.0 & 21 & 26.3 & 6 & 7.5 & - & - & 1 & 1.3 & 4.53 & $\begin{array}{l}\text { Strongly } \\
\text { Agree }\end{array}$ \\
\hline 7. & & & & & & & & & & & & \\
\hline $\begin{array}{l}\text { Seminar/traini } \\
\text { ng appropriate } \\
\text { to needs. }\end{array}$ & 42 & 52.5 & 28 & 35.0 & 8 & 10.0 & 2 & 2.5 & - & - & 4.37 & Agree \\
\hline 8. & & & & & & & & & & & & \\
\hline $\begin{array}{l}\text { Speakers/train } \\
\text { ers were } \\
\text { knowledgeable }\end{array}$ & 44 & 55.0 & 28 & 35.0 & 4 & 5.0 & 1 & 1.3 & 3 & 3.8 & 4.36 & Agree \\
\hline $\begin{array}{l}\text { 9. Ensured the } \\
\text { quality of the } \\
\text { activity }\end{array}$ & 48 & 60.0 & 24 & 30.0 & 5 & 6.3 & 3 & 3.8 & - & - & 4.46 & Agree \\
\hline
\end{tabular}


Judith Gabatin, Michelle Divino, Daisy Camua | ASEAN Journal of Community Engagement | Volume 3, Number 1, 2019

\begin{tabular}{|c|c|c|c|c|c|c|c|c|c|c|c|c|}
\hline \multirow[t]{2}{*}{ Item } & \multicolumn{2}{|c|}{$\begin{array}{c}\text { Strongly } \\
\text { agree }\end{array}$} & \multicolumn{2}{|c|}{ Agree } & \multicolumn{2}{|c|}{$\begin{array}{l}\text { Fairly } \\
\text { Agree }\end{array}$} & \multicolumn{2}{|c|}{ Disagree } & \multicolumn{2}{|c|}{$\begin{array}{l}\text { Strongly } \\
\text { disagree }\end{array}$} & \multirow[t]{2}{*}{ Mean } & \multirow{2}{*}{$\begin{array}{c}\text { Verbal } \\
\text { Interpreta } \\
\text { tion }\end{array}$} \\
\hline & $\mathrm{F}$ & $\%$ & $\mathrm{~F}$ & $\%$ & $\mathrm{~F}$ & $\%$ & $\mathrm{~F}$ & $\%$ & $\mathrm{~F}$ & $\%$ & & \\
\hline 10. & & & & & & & & & & & & \\
\hline Speakers/train & & & & & & & & & & & & \\
\hline ers were able & 53 & 66.3 & 17 & 21.3 & 8 & 10.0 & 1 & 1.3 & 1 & 1.3 & 4.49 & Agree \\
\hline to meet the & & & & & & & & & & & & \\
\hline objectives & & & & & & & & & & & & \\
\hline $\begin{array}{l}\text { 11. Encouraged } \\
\text { participation/i } \\
\text { nteraction }\end{array}$ & 51 & 63.8 & 24 & 30.0 & 3 & 3.8 & 1 & 1.3 & 1 & 1.3 & 4.54 & $\begin{array}{c}\text { Strongly } \\
\text { Agree }\end{array}$ \\
\hline $\begin{array}{l}\text { 12. Allowed } \\
\text { sharing of } \\
\text { insights }\end{array}$ & 57 & 71.3 & 15 & 18.8 & 6 & 7.5 & 1 & 1.3 & 1 & 1.3 & 4.58 & $\begin{array}{c}\text { Strongly } \\
\text { Agree }\end{array}$ \\
\hline $\begin{array}{l}\text { 13. Enough } \\
\text { allotted time } \\
\text { for the activity }\end{array}$ & 51 & 63.8 & 20 & 25.0 & 8 & 10.0 & 1 & 1.3 & - & - & 4.51 & $\begin{array}{c}\text { Strongly } \\
\text { Agree }\end{array}$ \\
\hline $\begin{array}{l}\text { 14. Enough } \\
\text { time allotted } \\
\text { for open forum }\end{array}$ & 52 & 65.0 & 19 & 23.8 & 8 & 10.0 & - & - & 1 & 1.3 & 4.51 & $\begin{array}{c}\text { Strongly } \\
\text { Agree }\end{array}$ \\
\hline
\end{tabular}

Source: Author (2018)

It can also be gleaned from the table nearly all (93.8\%) of the beneficiaries either strongly agreed or agreed to how the trainings encouraged them to participate and interact with each other (11th item). Most (92.5\%) of them answered "strongly agree" and "agree" to items pertaining to how knowledge gained from the trainings could be applied to future endeavors (2nd item) and how the trainings incorporated organized and easy-to-follow contents (4th item).

Furthermore, most (90.0\%) gave positive ratings to how the trainings achieved their expectations (1st item), tapped knowledgeable trainers (8th item), ensured the quality of the activity (9th item), and allowed sharing of insights (12th item). 
Judith Gabatin, Michelle Divino, Daisy Camua | ASEAN Journal of Community Engagement | Volume 3, Number 1, 2019

Table 4. Frequency distribution of participants' overall attitudes and mean response toward the quality of 2018 Sambalaran Camp Project

\begin{tabular}{|c|c|c|c|c|c|c|c|c|c|c|c|c|}
\hline \multirow{2}{*}{ Statement } & \multicolumn{2}{|c|}{ Excellent } & \multicolumn{2}{|c|}{ Very good } & \multicolumn{2}{|c|}{ Good } & \multicolumn{2}{|c|}{ Fair } & \multicolumn{2}{|c|}{ Poor } & \multirow{2}{*}{ Mean } & \multirow{2}{*}{$\begin{array}{c}\text { Verbal } \\
\text { Interpreta } \\
\text { tion }\end{array}$} \\
\hline & $\mathrm{F}$ & $\%$ & $\mathrm{~F}$ & $\%$ & $\mathrm{~F}$ & $\%$ & $\mathrm{~F}$ & $\%$ & $\mathrm{~F}$ & $\%$ & & \\
\hline Overall, how & & & & & & & & & & & & \\
\hline $\begin{array}{l}\text { will you rate the } \\
\text { quality the }\end{array}$ & 42 & 52.5 & 18 & 22.5 & 19 & 23.8 & - & - & 1 & 1.3 & 4.24 & Very Good \\
\hline project? & & & & & & & & & & & & \\
\hline
\end{tabular}

Source: Author (2018)

In Table 4, the results reveal that more than half (52.5\%) of the beneficiaries rated the extension project as "excellent" while almost a quarter $(22.5 \%)$ indicated a "very good" rating. This was further reflected in the mean score of 4.24, reflecting how they perceived the training as a very good project.

\subsection{Qualitative Evaluation Results}

\subsubsection{Beneficiaries' Perceptions Toward the Implementation 2017 Sambalaran Camp Project}

The qualitative evaluation results reveal that the participants acknowledged how the seminar-workshops and training could be a means for them to explore the possibility of engaging in a small business. Specifically, they drew a connection between the training and the possibility for livelihood. This was reflected in this statement from two food preservation training participants:

“..... I learned how to cook a jam that could help me start a business ......"

“...... I learned how I can grow business ......"

Further, the participants stated that they learned a lot from the activities. They took note of how the seminar-workshops could help them in managing their household affairs. A participant from the financial wellness and management talk had this realization: "What I should enrich is how I budget our money and how I should spend it." 
Judith Gabatin, Michelle Divino, Daisy Camua | ASEAN Journal of Community Engagement | Volume 3, Number 1, 2019

Consistent with the quantitative findings, the allotment of time for the activities was regarded by the participants as an aspect that still needs improvement. As evidenced by the following statements:

"...... The time and the materials used for cooking were not enough ......"

“..... I hope that there will be more time allotted for the training ......"

Some participants wanted the campus to provide additional trainings. Since there were only two to three hours spent for the activities, they wanted to have another day for the conduct of a Sambalaran camp. One participant even suggested to conduct a one-day activity for members of a Guiguinto-based organization.

\subsubsection{Beneficiaries' Perceptions Toward the Implementation 2018 Sambalaran Camp}

\section{Project}

Based on the qualitative evaluation of the training, the participants stated that they gained knowledge and skills which they could apply in their household. They also viewed the activity as an opportunity for them to explore the possibility of engaging in a small business. Three participants from shared these statements:

“...... We learned a lot, and we may use what we learned in our homes ......"

“...... We were able to learn something that can help us earn money even if we're at home ......"

“...... We can enrich our capability to engage in business for the benefit of our family

Consistent with the highly positive rating they gave to the quality of the training, the participants acknowledged how the extension team ensured the excellent quality of the activity despite the lack of resources. In this regard, they noted the following improvements that should be made by the extension provider:

"...... decent facilities in the training venue ......"

“..... Be prepared with all the ingredients and needed equipment ......"

“..... that cooking equipment which are better in quality ......" 
84

Judith Gabatin, Michelle Divino, Daisy Camua | ASEAN Journal of Community Engagement | Volume 3, Number 1, 2019

Given the success of the training, the participants wanted more individuals to partake in this project. They even requested for additional trainings like production of dishwashing liquid and fabric conditioner, soap making, and propagation of particular types of trees. As evidenced by this statement: "What I recommend is that there should be more of this type of project offered to us so that we'll have more learnings."

\subsection{Comparison of the Attitudes toward Sambalaran Camp Project between the 2017 and} 2018 batches of beneficiaries

As shown in Table 5, the mean scores for the beneficiaries from the 2017 Sambalaran and those from the 2018 project was significantly different, $t(140)=2.59, p=.011$. The first batch of beneficiaries ( $M=4.72, S D=0.43)$ reported a higher level of agreement than the second batch $(\mathrm{M}=4.49,0.63)$.

Table 5. t-test results and descriptive statistics of the attitudes toward the project's implementation between the two batches of Sambalaran beneficiaries

\begin{tabular}{|c|c|c|c|c|c|c|c|}
\hline \multirow{4}{*}{ Criterion / Variable } & \multicolumn{4}{|c|}{ Group } & \multirow{4}{*}{$\mathrm{t}$} & \multirow{4}{*}{ df } & \multirow{4}{*}{$\begin{array}{c}\text { Sig. } \\
\text { Value }\end{array}$} \\
\hline & \multirow{2}{*}{\multicolumn{2}{|c|}{$\begin{array}{c}2017 \\
\text { Beneficiaries } \\
(\mathrm{N}=74)\end{array}$}} & \multirow{2}{*}{\multicolumn{2}{|c|}{$\begin{array}{c}2018 \\
\text { Beneficiaries } \\
(\mathrm{N}=80)\end{array}$}} & & & \\
\hline & & & & & & & \\
\hline & M & SD & M & SD & & & \\
\hline $\begin{array}{c}\text { Attitudes toward } \\
\text { the Implementation } \\
\text { of the project }\end{array}$ & 4.72 & 0.43 & 4.49 & 0.63 & 2.59 & 140 & .011 \\
\hline
\end{tabular}

Source: Author (2017 \& 2018)

Table 6 shows that a significant difference existed between the two batches of beneficiaries as regards their attitudes towards the quality of the project, $t(148)=3.31$, $\mathrm{p}=.002$. The first batch $(\mathrm{M}=4.65, \mathrm{SD}=0.71)$ reported a higher positive rating than the second batch $(\mathrm{M}=4.24, \mathrm{SD}=0.90)$. 
Judith Gabatin, Michelle Divino, Daisy Camua | ASEAN Journal of Community Engagement | Volume 3, Number 1, 2019

Table 6. t-test results and descriptive statistics of the overall attitudes toward the project's quality between the two batches of Sambalaran beneficiaries

\begin{tabular}{|c|c|c|c|c|c|c|c|}
\hline \multirow{5}{*}{ Criterion / Variable } & \multicolumn{4}{|c|}{ Group } & \multirow{5}{*}{$\mathrm{t}$} & \multirow{5}{*}{ df } & \multirow{5}{*}{$\begin{array}{l}\text { Sig. } \\
\text { Value }\end{array}$} \\
\hline & \multirow{3}{*}{\multicolumn{2}{|c|}{$\begin{array}{c}2017 \\
\text { Beneficiaries } \\
(\mathrm{N}=74)\end{array}$}} & \multirow{3}{*}{\multicolumn{2}{|c|}{$\begin{array}{c}2018 \\
\text { Beneficiaries } \\
\quad(\mathrm{N}=80)\end{array}$}} & & & \\
\hline & & & & & & & \\
\hline & & & & & & & \\
\hline & M & SD & M & SD & & & \\
\hline $\begin{array}{l}\text { Attitudes toward } \\
\text { the quality of the }\end{array}$ & 4.65 & 0.71 & 4.24 & 0.90 & 3.31 & 148 & .002 \\
\hline project & & & & & & & \\
\hline
\end{tabular}

Source: Author (2017 \& 2018)

Overall, the results reflect certain positive aspects of the Sambalaran as an extension activity. First, it shows that the work plan crafted the extension arm of the university was designed based on the need's assessment. Second, the capabilities of the faculty as well as the resources of the university were maximized. Third, the creation of a team of extension service providers further highlighted the readiness of the Campus in responding to the needs of the communities. It helped that majority of the instructors had more than four years of experience in conducting extension services and more importantly, they were willing to partake in the project. These characteristics of a community engagement activity became crucial in fostering attitudinal changes among the intended beneficiaries. However, a closer look at the findings reveal that consistency should be given attention as regards the implementation of the project. The slight decrease in the level of agreement indicates that feedback was not fully utilized to make certain corrections on the course of carrying out a project. It is in this context that extension providers need to pause for a while, determine if they have to make necessary corrections or just continue moving forward with their efforts.

In the context of community engagement, the results indicate the relevance of a systematic approach to come up with evidence-based information that can be utilized to facilitate better decision-making. The integration of research skills becomes necessary in carrying out an extension service since the findings arising from conducting research would inform future decisions (Jackson \& Thomas, 2003). This academic practice is also 
86

Judith Gabatin, Michelle Divino, Daisy Camua | ASEAN Journal of Community Engagement | Volume 3, Number 1, 2019

highlighted that who noted the utilization of both subjective and objective data to evaluate a particular extension service (McKinnis et al., 2014).

The implementation of any community engagement project should thus not be considered an ordinary activity that requires only documentation (that is, merely taking videos, pictures, and providing terminal reports). The incorporation of research in any extension-related undertaking implies a more scientific approach to determine if it really has achieved its objectives. Sambalaran, for instance, has shown that there is still much to be done to improve it despite the positive ratings it garnered from the participants. A good case in point is how the significant difference that existed between the two batches of beneficiaries, in which the first batch reported a higher positive rating than the second batch, should be given attention by the implementers. This implies the need to utilize the evaluation findings as a feedback mechanism for reassessing the resources of the Campus and capabilities of the extension service providers. The use of such a feedback mechanism would inform future directions as regards the implementation of Sambalaran. This principle is supported by previous studies that place emphasis on feedback as crucial to the improvement of a project ( Zhang et al., 2011; Mosse \& Bottrell, 2015; Simmons et al., 2015).

In a more systematic way of obtaining feedbacks, Context, Input, Process, Product (CIPP) model can be of great help in assessing the pre-planning (Madaus et al., 2002), planning, implementation, and post-implementation phases of the project. While the results of this study have indicated that the project was able to address the participants' needs, the use of a model such as CIPP may be relevant in determining the weaknesses of Sambalaran. Questions thus arise regarding how it was carried out from the pre-planning stage using needs assessment to the post-implementation stage using the evaluation form, and whether the project was conducted in a cost-effective manner. Hence, drawing insights from the model would allow extension service implementers and providers to be more conscious of their decisions and actions, which they could further utilize to improve the overall design of the project.

\section{Conclusion}

This study set out to evaluate the implementation and quality of Sambalaran camp project, which was conducted in 2017 and 2018. It found that both batches of beneficiaries reported positive levels of agreement towards the project's 
Judith Gabatin, Michelle Divino, Daisy Camua | ASEAN Journal of Community Engagement | Volume 3, Number 1, 2019

implementation, as they either strongly agreed or agreed to how each component of the project was carried out. It was also shown that they perceived the project to be either excellent or very good in terms of its quality. In comparing the attitudes of the beneficiaries towards the implementation of the project, this study found that that the batch of beneficiaries that participated in the 2017 Sambalaran indicated a higher level of agreement than the succeeding batch.

The same goes with the ratings given to the quality of the project; the first batch gave a more positive rating than the second batch. Qualitative responses revealed that the seminars and trainings opened up possibilities for engaging in a small business. They acknowledged the knowledge and skills they gained from their participation in a one-day activity. However, they recognized that the activities, particularly the food preservation trainings, did not have enough required materials. Further, they noted the minimal amount of time allotted for a skills training activity. These observations were very much evident in the responses of the beneficiaries from the 2018 Sambalaran, which may explain why there were slight decreases in the level of agreement towards the project's implementation and the positive ratings of its quality (i.e., from "excellent" to "very good").

Following the evaluation results, there are a number of important changes which need to be made. In the area of preparation and production process, the facilities must be well equipped, and the activity are must be enclosed. Basic tools and equipment should be provided ahead of time. The coordinator should check if the materials the venue are well prepared and the trainers should always see to it that they are well-prepared and organized before conducting the activity. There should also be a short briefing with the trainers before starting the activity. If possible, there should be groupings when it is time for the participants to partake in the activity. Moreover, there is a need to photocopy sufficient course hand-outs and relevant materials that are ready for distribution before the training proper. Continuous training activities and technical assistance on product and marketing identification and simple bookkeeping for business may be conducted by the extension office. That will equip the participants basic knowledge and skills as well as right mindset in starting up a small business. 
88

Judith Gabatin, Michelle Divino, Daisy Camua | ASEAN Journal of Community Engagement | Volume 3, Number 1, 2019

\section{Acknowledgements}

We would like to extend our gratitude to the Research and Extension Offices of Bulacan State University - Meneses Campus for providing their support in the conduct of this research. We are particularly grateful to our fellow faculty members who served as extension service providers and helped us in the data collection procedures during the annual implementation of Sambalaran Camp Project.

\section{References}

Bulacan State University - University Extension Office. (2017). Research-based Extension Manual of Operation.

Education, C. on H. (2008). Guidelines for the CHED Outstanding Extension Program Award. Retrieved from https://ched.gov.ph/cmo-8-s-2008/

Jackson, D., \& Thomas, J. (2003). What is the role of extension educators in the first decade of the twenty-first century? Journal of Higher Education Outreach and Engagement, $10,37-44$.

Lynton, E. A. (1996). Ensuring the quality of outreach: The critical role of evaluating individual and collective initiatives and performance. Journal of Public Service and Outreach, 1(2), 16-22.

Madaus, F. F., Scriven, M., \& Stufflebeam, D. L. (2002). Evaluation Models: Viewpoints on Educational and Human Services Evaluation. In The CIPP Model for Program Evaluation (Vol. 2). Boston: Kluwer Academic Publishers.

McKinnis, D. R., Sloan, M. A., Snow, L. D., \& Garimella, S. V. (2014). A university engagement model for achieving technology adoption and performance improvement impacts in healthcare, manufacturing, and government. Journal of Higher Education Outreach and Engagement, 18(1), 187-213.

Mosse, J., \& Bottrell, C. (2015). The importance of place in evaluation of STEM partnerships between Universities and Schools in rural, remote and regional Australia. The Australasian Journal of University-Community Engagement, 10(2), 1943.

Oaks, F., Franklin, N., \& Bargerstock, B. A. (2008). Situating Outreach and Engagement in the University: Concepts, Challenges, and Opportunities.

Simmons, V. N., Klasko, L. B., Fleming, K., Koskan, A. M., Jackson, N. T., Noel-Thomas, S., \& 
Judith Gabatin, Michelle Divino, Daisy Camua | ASEAN Journal of Community Engagement | Volume 3, Number 1, 2019

Gwede, C. K. (2015). Participatory evaluation of a community-academic partnership to inform capacity-building and sustainability. Evaluation and Program Planning, 52, 19-26. https://doi.org/10.1016/j.evalprogplan.2015.03.005

Stocker, R. (2014). Extension and Higher Education Service- Learning: Toward a Community Development Service-Learning Model. Journal of Higher Education Outreach and Engagement, 18(1), 15-42.

UNESCO. (2015). Institutionalizing community university research partnerships: A user's manual.

Warner, L. A. (2014). Enhancing the Capacity to Create Behavior Change: Extension Key Leaders' Opinions about Social Marketing and Evaluation. Journal of Agricultural Education, 55(4), 176-190. https://doi.org/10.5032/jae.2014.04176

Zhang, G., Zeller, N., Griffith, R., Metcalf, D., Williams, J., Shea, C., \& Misulis, K. (2011). Using the Context, Input, Process, and Product Evaluation Model (CIPP) as a comprehensive framework to guide the planning, implementation, and assessment of service-learning programs. Journal of Higher Education Outreach and Engagement, 15(4), 57-84. 